\title{
"Glocal" Transnational Higher Education: A Case Study of a Finnish-Vietnamese Collaboration
}

\author{
Kirsi Hasanen \\ Tampere University \\ Finland
}

\begin{abstract}
This article presents a case study and an analysis of transnational higher education programs from the perspective of a multidirectional interplay between global processes and national and institutional interests. Using journal articles, ministry reports, websites and documents from higher education institutions, the analysis focuses on the national and local negotiation of the two-folded discourse in transnational higher education. The purpose of this paper is to provide an insight into the discourse prevalent in this field of research and shed light on the shared interests and converging aims of the transnational higher education partners. In this study, by applying approaches of discourse analysis, textual data are analyzed to make visible the assumptions on what is, can or will be understood as good and desirable in the context of transnational higher education. Methodologically, the study draws on the idea of the intertextuality of texts, emphasizing that texts are constructed in relation to other texts. Accordingly, the article shows how a case of transnational higher education between Finnish and Vietnamese higher education institutions can be gathered as an example of the hybrid global/local space of transnational education.
\end{abstract}

Keywords: transnational higher education; Finnish higher education; Vietnamese higher education; discourses; globalization

\section{Introduction}

In the last few decades, globalization, in the form of worldwide markets, has been no stranger to the field of higher education. An integrated world economy, expanding the international labor market, increased academic mobility, as well as the growth of information technology and the knowledge economy have all prompted the internationalization of higher education. Simultaneously, there has been a decrease in public funding for higher education in many countries, thus creating a need to gather funds from alternative sources. The increasing pursuit of market opportunities within higher education has led to the increased crossborder delivery of higher education, which has taken many forms. These forms vary from joint degree programs and the use of massive open online courses to 
international branch campuses and so-called education hubs. (Bannier, 2016; Healey, 2015; Lo, 2017.)

Accordingly, to map out the extant research and situate oneself within this field of research, a division must be made between the terms transnational higher education and cross-border higher education. Also, both borderless education and offshore education have been used with similar meanings. Thus, in the literature, research on cross-border higher education is concerned with issues relating to the provision, governance and quality assurance, while transnational higher education addresses questions relating to cultural differences as well as teaching and learning practices (Kosmützky \& Putty, 2016). Despite the varying terms used in academic literature, transnational higher education refers to the organization of education in a manner in which students are located in a different country from the degree-awarding institution. Therefore, instead of student mobility, the activity is based on the mobility of programs, institutions and teaching staff.

This study follows the definition of transnational higher education provided by Knight (2016), in which the degree-awarding institution, referred to as the home institution, is a Finnish public university operating under the national education system with regulatory frameworks for quality assurance. According to the Finnish University Act $(558 / 2009,9 \S)$ regarding transnational higher education, the programs must cover at least the costs incurring from it. Accordingly, transnational higher education is not to be delivered at the expense of the education provided locally, but it might be able to supplement reduced statefunding for universities and faculties. The programs of transnational higher education in focus here have been designed and executed in cooperation with two different Vietnamese higher education institutions, referred to in this study as the host institutions. Following the General Agreement on Trade in Services by the World Trade Organisation, these programs combine program and staff mobility. The degree programs are provided to students in their home country by combining distance learning with contact teaching, offered locally by the awarding institution's staff.

This article addresses transnational higher education from the perspective of a multi-directional interplay between global processes and national and institutional interests. Following a literature review on the prominent discourse concerning transnational higher education, the national and institutional contexts of a particular case of transnational higher education are analyzed. Using journal articles, ministry reports, websites and documents from national and higher education institutions, this article elucidates how parties trading on the symbolic capital of national higher education systems discursively negotiate and contextualize these activities. Building on the theory that discourses construct social practices and assign positions to social agents and vice versa (Gergen, 2009), the article concludes with a discussion on enriching the discursive standpoint in research concerning transnational higher education research. 


\section{The two-folded discourse: Cultural exchange and Westernisation}

"Many believe that modern information and communication technologies and the movement of people, ideas and culture across national boundaries are presenting new opportunities to promote one's culture to other countries and furthering chances for fusion and hybridization of culture. This position rests on the assumption that such flow of culture across borders is not new at all; only the speed has been accelerated. Others, however, contend that these same forces are eroding national cultural identities and that instead of creating new forms of cultures through hybridization - the forces are acting to homogenize cultures (in most cases, meaning westernization). Given that education has traditionally been seen as a vehicle of acculturation, these arguments are played out in terms of curriculum content, the language of instruction (English, increasingly) and the teaching/learning process of exported/imported programs. Both perspectives have strengths to their arguments" (Knight 2006, p. 56).

In this excerpt, from Higher Education Crossing Borders: A Guide to the Implications of the General Agreement on Trade in Services (GATS) for Crossborder Education, Knight (2006) summarises the two main views addressed in the scientific discussion relating to transnational higher education. Even though this guide was written more than a decade ago, based on a literary review of transnational higher education research, this binary appears to be continuous (also Wilkins \& Juusola, 2018). Chou et al. (2016) have highlighted that the literature on the globalization of higher education is divided: It is depicted either as an opportunity or a crisis. While crossing national borders might present more opportunities and cultural exchanges in the field of higher education, transnational higher education can also be depicted as a form of "modern-day colonialism" (Wilkins \& Juusola, 2018) that contains market-based claims of knowledge, where students become customers who shop for degrees in global higher education markets.

Thus, highlighting the global context in which both home and host institutions operate, it is clear that the legitimization of their international activity is based on the needs of universities to respond to the requirements of today's societies: to provide global competencies for their students and prepare them for globalized working environments (Haigh, 2014). Moreover, transnational higher education can be characterized as offering solutions for highly populated countries, where the demand for higher education cannot be met solely by local institutions (Bannier, 2016). Simultaneously, there are adequate concerns that while developing countries aim to develop their higher education system, to effectively join the global game, home institutions are more interested in the profitability and less in the strategic advancement of a hosting nation's higher education system (Altbach \& Knight, 2007; Healey, 2012; Healey \& Michael, 2015). Mindful of the trade-based nature of this activity; this perception implies that these objectives and agendas are mutually exclusive.

Accordingly, despite the Guidelines for Quality Provision in Cross-border Higher Education issued by the Organisation for Economic Co-operation and Development, and the United Nations Educational, Scientific and Cultural Organization (UNESCO) in 2005, there is an ongoing discussion in the scientific 
literature related to the quality assurance of programs of transnational higher education (Kosmützky \& Putty, 2016). The quality discussion stems from the critical intercultural perspective of the Westernisation of developing countries' higher education. Concretely, the prevailing issue in many studies has been related to the global standardization versus local adaption of the curriculum in transnational higher education programs (Shams \& Huisman, 2012). For example, international branch campuses have been criticized for transferring curricula to culturally different locations in which they have been designed for and taught by teachers, who have not participated in their development (Lane, 2011; LemkeWestcott \& Johnson, 2013).

To this end, and according to Djerasimovic (2014), research concerning transnational higher education has adopted a rather imperialistic premise. The critique is targeted at the determinist view of transnational higher education, where Western views are forced on developing countries. Thus, the mediation of Western views and pedagogics without any negotiations or re-contextualization can be seen as underrating the agency and cultural capital of the host country, its institutions and students. Additionally, Stella (2006) has highlighted that instead of looking for curriculum similarity in transnational higher education programs, the focus should be on curriculum comparability. Moreover, Waterval et al. (2017) have discussed the apparent lack of discussion on the definition of curriculum equivalence and who determines it. Consequently, Sidhu and Christie $(2015,302)$ suggest that transnational higher education takes place in hybrid global/local space as it is "shaped by specific, situated dynamics of global, national and local interests". This analytical concept enables an understanding of global and local processes as being simultaneous and influential in a multi-directional way.

Accordingly, this study presents a higher education partnership between Finnish and Vietnamese higher education institutions as an example of a hybrid global/local space of transnational higher education (ibid.). The Finnish and Vietnamese national and institutional contexts are analyzed in light of prevalent discourse on transnational higher education. Particular attention is paid on the local negotiation of transnational higher education discourse emphasising both opportunities for cultural exchange as well as concerns about Westernisation. Thus, a view is adopted that transnational higher education is nationally and institutionally negotiated and re-contextualized rather than merely being imposed. Consequently, the purpose of this study is to highlight the possible shared interests and converging aims among transnational higher education partners.

\section{Method and data}

Drawing on the theory of social constructivism (Berger \& Luckmann, 1984), this study relies on the understanding that while describing social reality, language is simultaneously re-constructing it. Accordingly, as power works through language, discourses constitute social structures and practices and assign positions to social agents. Thus, while indicating the ideal ways of being and acting, discourses concurrently legitimatize the desired state of affairs (Wodak \& Meyer, 2001). In this study, by applying approaches of discourse analysis, the textual data are analyzed to make visible the assumptions on what is, can or will 
be understood as good and desirable in the context of transnational higher education. Methodologically, the study draws on the idea of the intertextuality of texts, emphasizing that texts are constructed in relation to other texts (Fairclough, 2003). Thus, taking a broad view on intertextuality, the present assumptions are analyzed from a certain perspective: "What is said in a text is said against the background of what is unsaid, but taken as given" (ibid, 40) to extract the discourses deployed in the data.

Transnational higher education programs organized and delivered by a Finnish public university and Vietnamese higher education institutions, and their national and institutional contexts, form the case study for this article. The analysis relating to transnational higher education discourse in Vietnam is based on eight scientific articles and five websites relating to the internationalization of Vietnamese higher education. Thus, it is noteworthy that the secondary data, both from national and institutional levels, are produced in the context of the internationalization needs and requirements of both Finnish and Vietnamese higher education.

The analysis weighs on the Finnish data. The data gathered from Finland consist of five ministry-level reports and twelve institutional-level documents, including the university strategy and action plan to implement the strategy. Also, the policy guidelines for international degree programs, including transnational higher education programs set by the university's teaching council, are included in the data. The faculty-level data consist of project documents written by transnational higher education partners for various programs of international developmentcooperation for higher education, funded by the Finnish Ministry of Foreign Affairs. The faculty-level data also consist of education service-agreements signed between the partners. In addition to the division of costs and conditions of sale for educational services, the service agreements include co-produced curricula that combine courses from both institutions, teaching schedules, explanations of teaching procedures and regulations for the evaluation of studies. Memos from meetings with the partnering institutions and the home faculty's transnational higher education strategy are included in the data.

\section{Results}

Vietnamese higher education: Internationalization with traditional values

The discourse on the internationalization of higher education is not unfamiliar in the developing countries of the Asia-Pacific region (Mok, 2018), such as Vietnam. After the Chinese, French and Soviet influences on Vietnamese higher education, there has been a growing interest in establishing transnational higher education collaborations in the last few decades, especially with the United States, Australia and some European countries. Historically, the educational system in Vietnam has been based on the government's centralized planning, particularly the Vietnamese Ministry of Education and Training (MOET). Despite being strongly controlled by MOET, it has undergone decentralization reforms to enhance the effectiveness and autonomy of its institutions. One element of these decentralization reforms has been the internationalization of higher education (Trines, 2017; Economica Vietnam, 2018, WENR, 2014; 2017).

According to the research on the internationalization of Vietnamese higher education (Nha \& Tu, 2015; Nguyen et al., 2015; Tuyet, 2014), it is perceived to 
offer solutions to various challenges, including narrowing the gap between Vietnam and other countries concerning science, technology and equipping students to perform better in international and multicultural working environments (also Economica Vietnam, 2018). Thus, there is a need to fill the shortage of skilled workers in the country, and stop the brain drain to other countries. Additionally, there is a need to develop more research-oriented universities and increase the quality of teaching, the number of qualified teaching staff as well as staff and student mobility in higher education (Trines, 2017).

While there is reported interest in learning from educational standards, curriculum management, and delivery and the teaching practices of developed countries (Tuyet, 2014), it is also recognized that Vietnamese higher education institutions often lack resources and infrastructure, and are inexperienced with the various human, financial and administrative aspects relating to internationalization (Nguyen et al., 2015). Moreover, power relations between developing and developed countries and the quality aspects relating to transnational higher education programs delivered in Vietnam are acknowledged and discussed. Furthermore, Western views of pedagogy are often gathered in opposition to the prevailing Confucian culture in Vietnam, emphasizing the teacher as the primary source of knowledge and exams as measures of that knowledge (Pham \& Saltmarsh, 2013; Phan et al., 2016; Tran, 2013; Trung \& Swierczek, 2009).

Accordingly, in addition to MOET overseeing and approving the transnational higher education programs in Vietnam, there is a recognized concern that Western methods of teaching, organising and managing education might not correspond sufficiently with local context and culture. According to the mission of a Vietnamese university that is part of this case study, they aim to "provide the best higher education and research environment with the highest standards of professionalism to our students, ensuring that our graduates will be fully capable of competing and adapting to the global economy". At the same time, there is an emphasis on "taking pride and promoting the institution's traditional values" (University of Economics HCMC, 2020)

Consequently, for Vietnamese higher education to operate as an equal agent in the global higher education market, the conviction that transnational higher education programs should be provided in conjunction with foreign partners, in a manner ensuring the preservation of local perspectives and values, is noticeable from many different sources. Consequently, the Vietnam International Education Cooperation Department in MOET (2018) uses the term "joint training programs" when referring to transnational higher education programs.

It follows that while trying to attract more foreign-education providers to Vietnam, the Communist Party also seeks to maintain control over foreign institutions. Given the size of the Vietnamese higher education system, transnational higher education still constitutes just a small fraction of all the higher education activity in the country (McNamara \& Knight, 2015; Vietnam International Education Cooperation Department, 2018). Thus, based on the brief outlook on the internationalization of Vietnamese higher education, the national discourse appears somewhat similar to two-folded discourse on transnational higher education. Vietnamese higher education institutions are depicted as 
engines for implementing changes and improving society, while at the same time there is a national requirement to preserve local views and traditional values against the possible impacts of extensive Westernisation.

\section{Finnish higher education: Expanding the nation's education brand}

Since 2010, the Finnish Ministry of Education and Culture has adopted an ambitious stance in promoting Finnish education to become part of the global service economy. In the ministry's reports, the term "education export" is used when referring to transnational higher education. The education export strategy (2010, further clarified in 2013) is built on the belief that the Finnish education system is one of the best in the world due to Finland's high-ranking PISA (Programme for International Student Assessment) results. In 2016, the ministry published the Roadmap for Finnish Education Export for 2016-2019 (Ministry of Education and Culture 2016, 18), stating more cautiously that exporting education is a challenge that requires "new thinking" to turn Finnish education into a commodity that meets international demand. Thus, while implying that the Finnish educational outlook needs to be renewed, it also announces that future education exports will be viewed as "a normal activity" in Finnish higher education, indicating its current exceptionality.

The ministry's strategy has been criticized by Finnish scholars for being too vague (Schatz, 2016; Schatz et al., 2017) and for promoting export activities that are too foreign for higher education institutions (Cai et al., 2013). Simpson (2018) has criticized the deployment of high-quality education and equality-branding as a form of discursive construction that can be understood as ethnocentric because it fosters "othering" between nations. Thus, this kind of nation-branding can be perceived as being based on an over-simplistic image of education that ignores diversities and creates a hierarchy of nations (Schatz et al., 2017). Relating to aspects of quality and ethics, Finnish education exports are presented as being based on "sustainable development and mutual ethics" (Ministry of Education and Culture 2016, 2). Guidelines have been established by the Finnish Higher Education Evaluation Council to ensure quality control of Finnish transnational higher education programs (https://karvi.fi/en/higher-education/). These guidelines are based on the recommendations for cross-border higher education compiled by UNESCO and the Organisation for Economic Co-operation and Development. Nevertheless, it remains unspecified by the ministry as to what is understood by sustainable development and mutual ethics in the context of Finnish transnational higher education.

Consequently, it is noticeable that the national discourse on education exports in Finland leans heavily on the nation brand of high-quality education. Additionally, the Finnish Ministry for Foreign Affairs promotes education exports to Vietnam in the Cooperation between Finland and Vietnam 2016-2020 report (2017) by relying on the PISA brand of the country. What education would be exported, why and under what values is left for the Finnish higher education institutions to determine: apart from financial reasons, which mention "utilizing the brand to the fullest" (Ministry of Education and Culture 2013, 9), the reasons are not explicated in the reports. 
To summarise, as the term "education export" is used as the main term to refer to transnational higher education at the ministry documents, education is presented as a national commodity to be introduced to global education markets. The discourse on high-quality education circulates in ministry-level documents. Accordingly, it is suggested that by deploying Finland's strong tradition of education, the nation should not miss the opportunity to expand its brand of higher education. Thus, expanding the brand discourse discloses the context in which the nation's higher education is positioned as having much to offer. Moreover, as part of this discourse, Finnish higher education institutions are portrayed as future agents operating in global markets where they should engage with new thinking concerning higher education and welcome the thus-far unfamiliar activity of transnational higher education as part of their "normal activities", while simultaneously valuing sustainable development and mutual ethics.

\section{Finnish university: Transnational higher education as an ambiguously standard activity}

Following the prevalent discourse on the internationalization of higher education, the internationalization strategy for 2016-2020, set for a Finnish university engaged in transnational higher education activities, holds distinctly positive attributes and possibilities. Therefore, the need for internationalization is not questioned. According to the Teaching Council Policy Guidelines (2013) of this particular university, international degree programs, including transnational higher education programs, are "drawn up, evaluated and developed in the same manner as other degree programs". It is also stated that in addition to programs being interdisciplinary, research-based, high-quality and long-term, they "need to be organized in cooperation with strategic partner universities". Moreover, and as seen in ministry-level reports, the action plan to implement the university's strategy requests that the university will "offer ethically and socially sustainable transnational education". Despite being left unclarified, the emphasis on equivalence with localdegree programs offered to Finnish students and the co-production of transnational higher education programs suggests that the home institution recognizes the possibly unequal power relations in higher education markets and the importance of re-contextualization of curricula with the partner institution.

When analyzing the faculty-level documents, the notion of "we export what we $k n o w "$ is prevalent. Accordingly, the transnational higher education programs are offered in the faculty's research and teaching areas. Besides, there is a nationspecific element present that is related to the good reputation of Finnish public administration. Education is offered to public officials working in Vietnam, drawing on the fact that the Finnish public-administration system is ranked as one of the most efficient in the world; developing countries might find this ranking appealing. Therefore, in addition to the faculty's aim to take part in higher education markets, it is stressed that the capabilities and resources of the home institution mix well with customer requirements, thus creating a compatible foundation for collaboration (Lönnqvist et al., 2018).

Based on the service agreements, curricula and teaching schedules, the transnational higher education partnerships analyzed in this case study are built 
on the co-production and delivery of the curriculum. The provision of education is divided based on the expertise of the partner institutions. Thus, by incorporating local perspectives into Western curricula, there is a joint delivery of a "glocal" curriculum (Ramanau, 2016) taking place. According to the transnational higher education framework provided by Knight (2016, p. 39), this transnational higher education partnership would be situated between a "locally supported distance education program" and a "program with collaboration in design and delivery of curriculum and program" as the curriculum is co-produced and codelivered, but the degree is awarded only by the home institution.

What is clear from the strategy documents and memos is the notion of institutional capacity-building on both sides of the partnership. The possibility of research cooperation is recognized and mentioned by both parties but not emphasized. According to the transnational higher education spectrums defined by Healey and Michael (2015), from the home institution's perspective, this activity could be characterized as being teaching-led (in opposition to researchled) and based on special subjects to gain regional access. Nevertheless, even though most of the education has been provided by the degree-awarding institution, there is a yet unspecified indication in the service agreements that as the partnership continues, the host institutions would be interested in taking more responsibility for the curriculum delivery.

Accordingly, it is noteworthy that the countries and higher education institutions in this study are in different phases of internationalization concerning higher education. While one is opening up, the other is exporting. Activities relating to transnational higher education are quite recent, so there is still a lot to be learned from curriculum design, management of transnational higher education programs, student guidance and supervision in this joint venture. Moreover, the present strategic directions at both national and institutional levels can alter depending on changing demand, national regulations and available resources in both countries. Despite remarks about capacity-building and knowledge-transfer, it has not been given much precedence thus far.

As the host institutions are interested in modernizing and internationalizing their curricula to attract students and meet the national requirements for internationalizing Vietnamese higher education institutions, the home faculty describes transnational higher education, in the Education export strategy of 2014, as a way in which to potentially "widen the impact of the faculty's activities" and "offer staff new international teaching possibilities". However, at the Finnish universities, international teaching experience has not been supported or valued when compared to international research activities and co-operation. This is stated in the education export strategy of the Ministry of Education and Culture (2010) as a weakness in Finnish higher education.

Consequently, from an institutional perspective, transnational higher education programs are presented as part of the university's conventional activities, as they follow the guidelines and regulations of national degree programs offered to Finnish students. Nevertheless, the thus-far unestablished position and ambiguity of transnational higher education become visible, as the terms describing transnational higher education are used interchangeably in the university- and faculty-level documents. Moreover, the indefinite references to ethically and 
socially sustainable transnational higher education and the emphasis on cooperation, as a premise for partnership, highlights the Westernisation discourse somewhat acknowledged and reflected upon at the institutional level. Thus, the "glocal" curricula liberate home countries from the supposed Westernisation of curricula.

\section{Conclusion}

The varying use of terms, ranging from "education export" to "joint training programs" and to "transnational education" in the data indicates that there are local, national and institutional negotiations of the term used to describe transnational higher education. Accordingly, Finnish higher education can be depicted concurrently as an exported national commodity as well as a form of regular activity of local universities. Similarly, while there is a necessity for preservation and control, Vietnamese higher education is simultaneously aiming to partake in the global education market. To conclude, the national-level discourse on transnational higher education in both countries draws from national traditions and history, brands and values of higher education. Moreover, it could be perceived that the discourse on the Westernisation of higher education with unequal power relations is recognized, even though it is not explicitly articulated. Consequently, the local negotiation and re-contextualization of the global trends and discourses demonstrate how this case study can be depicted as one example of a hybrid global/local space of transnational higher education. While guided by national-level interests and discourse, higher education institutions simultaneously possess power as the operating actors in this field. Consequently, a more nuanced and multi-faceted view of imposed globalization and Westernisation could still be called for in transnational higher education research. As discourses display what is considered legitimate, valuable as well as unvalued, they also assign positions for transnational higher education partners and identifies social practices of note. Accordingly, the discussion among researchers and policymakers should also include an institutional-level analysis of transnational higher education case studies. This study indicates that there is agency negotiated through and within the internationalization of higher education discourse at the national and institutional levels on both sides of transnational higher education partnerships. As a result of this analysis, a more versatile and distinctive view of this activity is presented.

\section{References}

Altbach, P. G., \& Knight, J. (2007). The internationalization of higher education: Motivations and realities. Journal of Studies in International Education, 11(3-4), 290305. https://dx.doi.org/10.1177/1028315307303542

Bannier, B. J. (2016). Global trends in transnational education. International Journal of Information and Education Technology, 6(1), 80-84. https://dx.doi.org/10.7763/IJIET.2016.V6.663

Beckner, C., Blythe, R., Bybee, J., Christiansen, M. H., Croft, W., Ellis, N. C., \& Schoenemann, T. (2009). Language is a complex adaptive system: Position paper. Language Learning, 59, 1-26. https:/ / dx.doi.org/10.1111/j.1467-9922.2009.00533.x

Berger, P. L., \& Luckmann, T. (1984). The social construction of reality: A treatise in the sociology of knowledge. Penguin. 
Cai, Y., Hölttä, S., \& Lindholm, N. (2012). Establishing sub-campuses in China: A Finnish perspective. Journal of Research in International Education, 12(2), 142-154. https://dx.doi.org/10.1177/1475240913482834

Charness, N., \& Boot, W. R. (2009). Aging and information technology use potential and barriers. Current Directions in Psychological Science, 18(5), 253-258.

Chou, M-H., Kamola, I., \& Pietsch, T. (2016). The transnational politics of higher education: Contesting the global / transforming the local. Routledge.

Coget, J. F. (2011). Technophobe vs. techno-enthusiast: Does the Internet help or hinder the balance between work and home life? The Academy of Management Perspectives, 25(1), 95-96.

Djerasimovic, S. (2014). Examining the discourses of cross-cultural communication in transnational higher education: From imposition to transformation. Journal of Education for Teaching, 40(3), 204-216. https://dx.doi.org/10.1080/02607476.2014.903022

Dorrian, J., \& Wache, D. (2009). Introduction of an online approach to flexible learning for on-campus and distance education students: Lessons learned and ways forward. $\begin{array}{llll}\text { Nurse } & \text { Education } & \text { Today, 29(2), }\end{array}$ https://dx.doi.org/10.1016/j.nedt.2008.08.010

Economica Vietnam. (2018, November). Law on amendments to the law on higher education. Retrieved from https://www.economica.vn/ /Content/files/LAW \%26 REG/Law on Amendment to Law Higher Education 2018.pdf

Fairclough, N. (2003). Analysing discourse: Textual analysis for social research. Routledge.

Gergen, K. J. (2009). Relational Being: Beyond Self and Community. Oxford Scholarship Online. Retrieved from https://ebookcentral.proquest.com/lib/tampere/detail.action?docID=472069

Haigh, M. (2014). From internationalisation to education for global citizenship: A multilayered history. Higher Education Quarterly, 66(1), 6-27. https://dx.doi.org/10.1111/hequ.12032

Healey, N. (2012). Why do English universities really franchise degrees to overseas providers? Higher Education Quarterly, 67(2), 180-200. https://dx.doi.org/10.1111/hequ.12012

Healey, N. (2015). Managing international branch campuses: What do we know? Higher Education Quarterly, 66(4),386-409. https://dx.doi.org/10.1111/hequ.12082

Healey, N., \& Michael, L. (2015). Towards a new framework for analysing transnational education. Higher Education Policy, 28, 369-391. https://dx.doi.org/10.1057/hep.2014.17

Knight, J. (2006). High education crossing borders: A guide to the implications of the general agreement on trade in services (GATS) for cross-border education. Commonwealth of Learning. Retrieved from https://unesdoc.unesco.org/ark:/48223/pf0000147363

Knight, J. (2016). Transnational education remodelled: Toward a common transnational higher education framework and definitions. Journal of Studies in International Education, 20(1), 34-47. https://dx.doi.org/10.1177/1028315315602927

Knight, J., \& McNamara, J. (2015). Transnational education: A classification framework and data collection guidelines for international programme and provider mobility (IPPM). British Council. $\quad$ Retrieved from https://www.britishcouncil.org/education/ihe

Kosmützky, A., \& Putty, R. (2016). Transcending borders and traversing boundaries: A systematic review of the literature on transnational offshore, cross-border, and borderless higher education. Journal of Studies in International Education, 20(1), 833. https://dx.doi.org/10.1177/1028315315604719 
Lane, J. E. (2011). Global expansion of international branch campuses: Managerial and leadership challenges. New Directions for Higher Education, 155, 5-17. https://dx.doi.org/10.1002/he.440

Lemke-Westcott, T., \& Johnson, B. (2013). When culture and learning styles matter: A Canadian university with Middle-Eastern students. Journal of Research in International Education, 12(1), 66-84. https://dx.doi.org/10.1177/1475240913480105.

Lo, W. Y. W. (2017). After globalisation: A reconceptualization of transnational higher education governance in Singapore and Hong Kong. Higher Education Quarterly 72, 3-14. https://dx.doi.org/10.1111/hequ.12137

Lönnqvist, A., Laihonen, H., Cai, Y., \& Hasanen, K. (2018). Re-framing education export from the perspective of intellectual capital transfer. Journal of Studies in International Education, 22(4), 353-368. https://dx.doi.org/10.1177/1028315318773141.

Ministry for Foreign Affairs. (2017). Cooperation between Finland and Vietnam 20162020. Ministry for Foreign Affairs, Finland. Retrieved from https://um.fi/documents/35732/48132/cooperation_between_finland_and_vie tnam_2016_2020

Ministry of Education and Culture. (2010). Finnish education export strategy. Based on the decision-in-principle by the government of Finland on April 24, 2010. Ministry of Culture and Education, Finland. Retrieved from http://julkaisut.valtioneuvosto.fi/bitstream/handle/10024/75525/okm11.pdf?s equence $=1$ andisAllowed $=\mathrm{y}$

Ministry of Education and Culture. (2013). International education markets and Finland. Ministry of Culture and Education, Finland. Retrieved from http://julkaisut.valtioneuvosto.fi/bitstream/handle/10024/75298/tr09.pdf?seq uence $=1$ andisAllowed $=\mathrm{y}$

Ministry of Education and Culture. (2016). Roadmap for education export 2016-2019. Ministry of Education and Culture. Retrieved from http://www.minedu.fi/export/sites/default/OPM/Julkaisut/2016/liitteet/ok m9pdf?lang=fi

Mok, K. H. (2018). Does internationalisation of higher education still matter? Critical reflections on student learning, graduate employment and faculty development in Asia. Higher Education Quarterly 72, 183-193. https://dx.doi.org/10.1111/hequ.12170

Nguyen, D. P., Vickers, M., Ly, T. M. C., \& Tran, M. D. (2015). Internationalizing higher education in Vietnam. Education + Training 58(2), 193-208. https://dx.doi.org/10.1108/ET-08-2015-0072

Nha, N. V., \& Tu, V. N. (2015). Higher education reform in Vietnam: Current situation, challenges and solutions. VNU Journal of Science 31(4), 85-97. Retrieved from https://js.vnu.edu.vn/SSH/article/view/245

Pham, L., \& Saltmarsh, D. (2013). International students' identities in a globalized world: Narratives from Vietnam. Journal of Research in International Education, 12(2), 129141. https://dx.doi.org/10.1177/1475240913481171

Phan, T. N., Lupton, M., \& Watters, J. J. (2016). Understandings of the higher education curriculum in Vietnam. Higher Education Research and Development, 35(6), 12561268. https://dx.doi.org/10.1080/07294360.2016.1149693

Ramanau, R. (2016). Internalization at a distance: A study of the online management curriculum. Journal of Management Education, 40(5), 545-575. https://dx.doi.org/10.1177/1052562916647984 
Schatz, M, Popovi, A., \& Dervin, F. (2017). From PISA to national branding: Exploring Finnish education ${ }^{\circledR}$. Discourse: Studies in the Cultural Politics of Education, 38(2), 172-184. https://dx.doi.org/10.1080/01596306.2015.1066311

Schatz, M. (2016). Engines without fuel? - Empirical findings on Finnish higher education institutions as education exporters. Policy Futures in Education, 14(3), 392-408. https://dx.doi.org/10.1177/1478210316633950

Shams, F., \& Huisman, J. (2012). Managing offshore branch campuses: An analytical framework for institutional strategies. Journal of Studies in International Education, 16(2), 106-127. https://dx.doi.org/10.1177/1028315311413470

Sidhu, R. K., \& Christie, P. (2015). Transnational higher education as a hybrid global/local space: A case study of a Malaysian-Australian joint venture. Journal of Sociology, 51(2), 299-316. https://dx.doi.org/10.1177/1440783314521882

Simpson, A. (2018). The dialogism of ideologies about equality, democracy and human rights within Finnish education. Many voices and many faces (Doctoral dissertation). University of Helsinki. Retrieved from http:// urn.fi/URN:ISBN:978-951-51-3929-0

Stella, A. (2006). Quality assurance of cross-border higher education. Quality in Higher Education, 12(3), 257-276. https://dx.doi.org/10.1080/13538320601072859

Tran, T. T. (2013). Limitation on the development of skills in higher education on Vietnam. Higher Education, 65, 631-644. Retrieved from https://www.jstor.org/stable/23473516

Trines, S. (2017). Education in Vietnam. Retrieved from https://wenr.wes.org/2017/11/education-in-vietnam

Trung, T. Q., \& Swierczek, F. W. (2009). Skills development in higher education in Vietnam. Asia Pacific Business Review, 15(4), 565-586. https://dx.doi.org/10.1080/13602380802364175.

Tuyet, T. T. (2014). Internationalization of higher education in Vietnam. Opportunities and challenges. Journal of Science: Foreign Studies, 30(3), 61-69. Retrieved from https://js.vnu.edu.vn/FS/article/view/456

University of Economics HCMC. (2020). Mission - Vision. Retrieved from http://ueh.edu.vn/detail.aspx?id=707andtl=Mission-Vision

Vietnam International Education Cooperation Department, MOET. (2018, November 28). Retrieved from https://en.moet.gov.vn/education-and-training/Pages/Highereducation.aspx

Waterval, D. G. J., Tinnemans-Adriaanse, M., Meziani, M., Driessen, E., Scherpbier, A., Mazrou, A., \& Frambach, J. (2017). Exporting a student-centered curriculum: A home institution's perspective. Journal of Studies in International Education, 21(3), 278-290. https://dx.doi.org/10.1177/1028315317697542

WENR. (2014). Higher Education in Vietnam. Retrieved from https://wenr.wes.org/2014/05/higher-education-in-vietnam

WENR. (2017). Education in Vietnam. Retrieved from https://wenr.wes.org/2017/11/education-in-vietnam

Wilkins, S., \& Juusola, K. (2018). The benefits and drawbacks of transnational higher education. Myths and realities. Australian University Review, 60(2), 68-76. Retrieved from https://search.informit.com.au/documentSummary;dn=818837312482658;res=I ELHSS

Wodak, R., \& Meye, M. (2001). Methods of critical discourse analysis. SAGE. 